IZA DP No. 7406

Transfer Behaviour in Migrant Sending Communities

Tanika Chakraborty

Bakhrom Mirkasimov

Susan Steiner

May 2013 


\title{
Transfer Behaviour in Migrant Sending Communities
}

\author{
Tanika Chakraborty \\ Indian Institute of Technology Kanpur \\ and IZA \\ Bakhrom Mirkasimov \\ Humboldt University of Berlin \\ and DIW Berlin \\ Susan Steiner \\ Leibniz Universität Hannover, \\ DIW Berlin and IZA
}

Discussion Paper No. 7406

May 2013

IZA

P.O. Box 7240

53072 Bonn

Germany

Phone: +49-228-3894-0

Fax: +49-228-3894-180

E-mail: iza@iza.org

Any opinions expressed here are those of the author(s) and not those of IZA. Research published in this series may include views on policy, but the institute itself takes no institutional policy positions. The IZA research network is committed to the IZA Guiding Principles of Research Integrity.

The Institute for the Study of Labor (IZA) in Bonn is a local and virtual international research center and a place of communication between science, politics and business. IZA is an independent nonprofit organization supported by Deutsche Post Foundation. The center is associated with the University of Bonn and offers a stimulating research environment through its international network, workshops and conferences, data service, project support, research visits and doctoral program. IZA engages in (i) original and internationally competitive research in all fields of labor economics, (ii) development of policy concepts, and (iii) dissemination of research results and concepts to the interested public.

IZA Discussion Papers often represent preliminary work and are circulated to encourage discussion. Citation of such a paper should account for its provisional character. A revised version may be available directly from the author. 


\section{ABSTRACT}

\section{Transfer Behaviour in Migrant Sending Communities*}

We study how international migration changes the private transfers made between households in the migrant sending communities of developing countries. A priori, it is indeterminate whether migration and remittances strengthen or weaken the degree of private transfers in these communities. From a policy perspective, public income redistribution programmes would have an important role to play if migration reduced the extent of private transfers. Using household survey data from Kyrgyzstan, we find that households with migrant members (as well as households receiving remittances) are more likely than households without migrants (without remittances) to provide monetary transfers to others, but less likely to receive monetary transfers from others. This suggests that migration is unlikely to lead to a weakening of private transfers.

JEL Classification: D63, F22, O12, 130

Keywords: private transfers, cash and labour exchange, migration, Kyrgyzstan, Central Asia

Corresponding author:

Susan Steiner

Institute for Development and Agricultural Economics

Leibniz Universität Hannover

Königsworther Platz 1

30167 Hannover

Germany

E-mail: steiner@ifgb.uni-hannover.de

\footnotetext{
* This paper was written within the research project "Economic Transformation, Household Behaviour and Well-Being in Central Asia. The Case of Kyrgyzstan", which was funded by the Volkswagen Foundation. We are grateful to Kathryn Anderson, Ainura Asamidinova, Charles Becker, Margherita Comola, Shamsia Ibragimova, and Mariapia Mendola for helpful comments on earlier versions of the paper. We also received crucial feedback from participants of workshops and conferences in Moscow, Chicago, Bonn, Delhi, Einsiedeln, Bishkek, Madison, and Almaty. Furthermore, our colleagues at the DIW Department for Development and Security provided invaluable comments. We also thank the German Research Centre for Geosciences in Potsdam, Eugene Huskey and Mohammad Hamayoon Majidi for providing us with different types of data and Philipp Jaeger and Zalina Sharkaeva for excellent research assistance.
} 


\section{Introduction}

Rural households in developing countries employ a wide range of strategies to deal with the harsh living conditions that many of them face. Two of these strategies are migration to economically more advantaged places and exchanging informal private transfers with the households in their social networks. ${ }^{1}$ In this paper, we study the implications of international migration for private transfer behaviour in the migrant sending communities.

On the one hand, sending a household member abroad is likely to decrease this household's income variability because income is obtained from various sources. This makes the household less dependent on transfers from other households within the community. If, therefore, migration reduced the extent of private transfers made within migrant sending communities, this could have serious consequences for those households without migrants abroad. Policy makers should be aware that private transfers may have to be substituted by public transfers. On the other hand, households that receive remittances from migrants might transfer more money to other households in the community in order to insure them (Morten 2010). If, then, migration increased the extent of private transfers made, this would mean that migration increased the welfare not only of migrant households but also of non-migrant households. ${ }^{2}$ The design of migration policies should take this potential effect into account.

Despite the vast literature on migration on the one hand and private transfers on the other, only few studies make a connection between these two aspects. Gallego and Mendola (forthcoming) explore whether migration increases participation of the migrant sending households in formal and informal social networks in Mozambique. They show that households which receive remittances or have return migrants participate more in social networks. Morten (2010) investigates the role played by remittances in insuring migrant sending households and their networks in India. She finds that remittances respond to aggregate shocks to household networks and hence contribute to informal risk-sharing in the sending communities. In a more recent study, Morten (2012) acknowledges that both private risk-sharing transfers and migration are mechanisms for households to informally insure against shocks. She develops a dynamic model of risk-sharing with endogenous migration and finds that risk-sharing reduces migration and migration in turn reduces risk-sharing. We add to this literature in the following way. First, we investigate how migration changes the private transfer behaviour of households left behind, in contrast to Gallego and Mendola

\footnotetext{
${ }^{1}$ Private transfers function like means-tested income redistribution flowing from better off to worse off households. They also act like risk-sharing mechanisms with income flowing to households that experienced income shocks (Cox and Fafchamps 2008).

${ }^{2}$ Ratha et al. (2011) provide an excellent review of the literature on the welfare implications of migration.
} 
(forthcoming) who analyse participation in social networks. Second, we do not restrict ourselves to risk-sharing transfers, as in Morten (2010; 2012), but are interested in all private transfers, in times of income shocks and otherwise.

Our third contribution to the literature is that we distinguish between monetary and non-monetary (i.e. labour) private transfers. It is possible that some households (potentially those that receive remittances) provide monetary transfers and other households (potentially those that do not have migrants abroad) return non-monetary help. If so and we only considered monetary transfers, we would conclude that private transfers were unreciprocated. If, however, we took both monetary and non-monetary transfers into account, we would be able to identify reciprocal behaviour (Schechter and Yuskavage 2011). We thereby relate to studies on the motives for private transfers. These studies assert that understanding transfer motives is essential for policy makers since the different underlying motives have different implications for the impact of public transfer programmes (Schokkaert 2006; Cox and Fafchamps 2008). Specifically, the impact of such programmes is potentially offset by a reduction in private transfers, if these were made out of pure altruism. This is in contrast to transfers motivated by self-interest or reciprocity, which are not expected to be crowded out by public transfers. This literature largely ignores the possibility of labour transfers. ${ }^{3}$

In this paper, we study whether international migration weakens or strengthens the extent of private transfers within rural migrant sending communities in Kyrgyzstan. Specifically, we compare the transfer behaviour of households that have migrants abroad with that of households that do not have migrants abroad. Since the turn of the century, migration has been mostly economically driven with migrants from Kyrgyzstan seeking income earning opportunities in better-off countries, mainly Russia (Lukashova and Makenbaeva 2009). The migration corridor from Kyrgyzstan and the other Central Asian republics to Russia is now considered to be the second largest in the world, following the route from Mexico to the United States (World Bank 2010). It is unclear how such massive outmigration changes the system of private transfers and mutual help that is common in Central Asia. Informal social networks based on kinship and neighbourhood played a large role for obtaining access to information and goods in pre-Soviet times as well as during the Soviet period and they are still important today in Kyrgyzstan (Coudouel et al. 1997; Kuehnast and Dudwick 2002). Anecdotal evidence from Howell (1996) finds that borrowing food and money from relatives

\footnotetext{
${ }^{3}$ Exceptions are studies on intergenerational transfers, such as Cox (1987) and Cox and Rank (1992). They find that labour transfers are an important mechanism for the younger generation to exchange for monetary transfers from the older generation.
} 
and neighbours in times of economic stress is a common practice in southern Kyrgyzstan, the part of the country with the currently largest migration rate.

Empirical identification of the effect of migration on transfer behaviour within migrant sending communities can be confounded by simultaneity and unobserved heterogeneity. Simultaneity can be a problem if communities with more private transfers among households experience more out-migration. Unobserved heterogeneity is a serious concern because differences between migrant and non-migrant households might influence both migration and private transfer decisions (McKenzie et al. 2010). To address these problems, we use longitudinal data from the Life in Kyrgyzstan (LIK) household survey, run a lagged regression model, and match migrant and non-migrant households on a wide range of variables using propensity score matching methods.

Our findings show that migrant households are more likely than non-migrant households to provide monetary transfers to others. We cannot clearly identify whether monetary transfers flow from migrant to non-migrant households, but our results are suggestive of this behaviour. This is because non-migrant households are more likely to receive monetary transfers than migrant households. This provides some evidence that migrant households, through their access to remittance income, insure their social networks against shocks and/or redistribute income to poorer households in the community. Furthermore, we find that non-migrant households are more likely than migrant households to provide labour assistance to others. This result is possibly driven by relative labour abundance in non-migrant households. Indeed, among households with dependants, migrant households are more likely to receive labour help from others.

The rest of this paper is organized as follows. We discuss alternative mechanisms for the relationship between migration and households' transfer behaviour in the next section. Section 3 discusses our empirical strategy. Section 4 introduces the LIK data. Section 5 presents the estimation results. We conclude the paper by summarizing our findings and discussing their policy implications in section 6.

\section{Analytical Framework}

We provide an overview of the mechanisms through which migration may influence household transfer behaviour. We distinguish between the effect of migration and the effect of remittances since having a migrant abroad does not necessarily have the same consequences for household welfare as receiving remittances. Furthermore, households that have migrants abroad do not always receive remittances, and households that receive remittances do not 
always receive them from close family members but possibly from extended family members or non-relatives.

Migration may strengthen the extent of monetary transfers in migrant sending communities if there is a co-insurance scheme between the migrant and the household left behind (Stark and Lucas 1988) and if other community members provide part of the insurance that flows to the migrant (mechanism 1). Migration may weaken the extent of monetary transfers, however, because a high rate of migration at the community level decreases commitment in mutual transfer arrangements. Migration of community members decreases the credibility of future reciprocity, and reciprocity is necessary to sustain non-enforceable transfer arrangements (Ligon et al. 2002). ${ }^{4}$ Households may choose not to provide monetary transfers to others, who they think are likely to migrate as reciprocity would then be less possible in the future (mechanism 2). The same logic applies to non-monetary transfers; households may not provide labour to other households within their community if they expect members of these households to be abroad in the future (mechanism 3). Yet, it is also reasonable to expect more labour transfers to households that have migrants abroad because usually young male adults migrate while the elderly, women, and children are left behind (mechanism 4). For example, grandparents who stay with their grandchildren are likely to use more outside labour to help with house repairs or accompany grandchildren to school when their adult children are absent.

We turn to remittances. Remittances may increase the extent of monetary transfers because they provide access to income that is uncorrelated with income generated within the community. Remittance-receiving households may thus be better able to provide transfers to their networks and insure them against aggregate shocks (Morten 2010) (mechanism 5). ${ }^{5}$ This argument builds on Foster and Rosenzweig (2001) who study the effect of different degrees of altruism and income variance between transfer partners on the size of transfers, using panel data from rural South Asia. They show that risk-sharing is achieved with a high degree of altruism and a low level of income correlation between transfer partners. Some risk-sharing even takes place in the absence of altruism. Alternatively, remittances may be positively related to monetary transfers because they may provide more stable income to the remittance-

\footnotetext{
${ }^{4}$ Ligon, Thomas and Worrall (2002) assume that informal insurance arrangements are sustained by means of penalties for breach of contract. These penalties include peer group pressure or being brought before a village council with the threat of future exclusion from insurance at the community level.

${ }^{5}$ Remittances respond to income shocks of the receiving household and so have an insurance motive (Lucas and Stark 1985; Rosenzweig 1988; Fafchamps and Lund 2003; Yang and Choi 2007). Giesbert, Steiner and Bendig (2011) show that households, which receive remittances, are less likely to have formal insurance - which also speaks for an insurance function of remittances. What has not been studied much is whether remittances sent for insurance are shared with the social network.
} 
receiving household making it a low risk member in risk-sharing arrangements (Gallego and Mendola forthcoming) (mechanism 6). If private transfers are made to redistribute income, rather than to share risk, more monetary transfers may be expected if the better off partner in the income redistribution network is the one who receives the remittances (mechanism 7). In contrast, households may reduce their monetary transfers for income redistribution if the remittance receiver is the previously worse off partner in the network (mechanism 8).

Remittances may decrease monetary transfers in the migrant sending community because they make the outside option of autarky more attractive for remittance-receiving households; risk-sharing is likely to fall whenever the value of autarky increases relative to the value of being in the contract (Albarran and Attanasio 2003). Remittance-receiving households can use remittances to insure against shocks and do not need to engage in mutual transfer arrangements within the community (Morten 2010) (mechanism 9). Remittances may allow receiving households to exchange money for labour (Schechter and Yuskavage 2011). Specifically, households that receive remittances may transfer money to other households and receive labour in return. This seems particularly likely when the adult members of the household migrate (mechanism 10).

In sum, migration can have a positive or negative impact on household private transfers, and the relationship between remittances and private transfers is equally indeterminate. While we cannot identify the mechanisms of how migration affects transfers clearly in our empirical analysis, given the nature of our data, we interpret our findings in light of these theoretical considerations.

\section{Empirical strategy}

Our aim is to understand whether migration and remittances help or hinder the degree of cooperation in private transfers between households in the absence of formal credit markets. We investigate the extent to which migrant households differ from non-migrant households in their transfer behaviour and test whether migrant households provide more monetary or nonmonetary help to other members of the community than non-migrant households. One problem with estimating the effect of current migration on the current level of private transfers is that private transfers made to a household might affect this household's migration decision. Households that receive transfers might be less likely to send a migrant abroad because there is less need to explore uncorrelated income earning opportunities. To ameliorate this simultaneity bias, we exploit the panel structure of our data and estimate a lagged model where the migration decision is made before the household makes or receives transfers. We 
estimate the effect of migration status of a household in period t-1 on transfer behaviour in period t according to the following specification:

$$
Y_{i j t}=\alpha+\beta_{1} M_{i j t-1}+\beta_{2} X_{i j t}+\beta_{3} D_{j}+\varepsilon_{i j t}
$$

where $Y_{i j}$ is an indicator of whether transfers are provided (received) by household i residing in community j. We estimate separate models for monetary and non-monetary transfers and separate models for the provision and receipt of transfers. Equation (1) is thus estimated for four alternative dependent variables. In our first step, we define $M_{i j}$ as a dummy variable indicating whether household $\mathrm{i}$ in community $\mathrm{j}$ has a migrant member or not. A household has a migrant member if an adult member has been working abroad for more than a month in the last 12 months. In our second step, we define $M_{i j}$ as a dummy variable indicating whether a household receives remittances or not. A household is a remittance-receiving household if it has received any money from abroad during the last 12 months. The person who sends these remittances may or may not be a member of this household. We control for other household level variables, $X_{i j}$, that may generate differential transfer behaviour between migrant and non-migrant households or remittance and non-remittance households.

$X_{i j}$ includes socio-demographic variables, namely age, gender, marital status, education, and ethnicity of the household head. We also control for household size and the ownership of wealth. The wealth index is constructed using principal components analysis based on ownership of household assets such as land, a car, a computer, a washing machine, and the number of livestock. It is possible that involvement in social networks drives both the migration decision and transfer behaviour. To address this concern, we control for membership in a number of social groups (such as professional unions, credit and savings groups, neighbourhood committees, and sports groups).

The community is the potential network of a household. We define the community as the rayon (district). The average rayon in Kyrgyzstan consists of 45 villages $^{6}$ with a population of 18,384 households. We control for community fixed effects, $D_{j}$, which allows us to compare the behaviour of migrant and non-migrant households, or remittance and nonremittance households, within each community.

$\beta_{1}$ is the coefficient of interest to us. If $\beta_{1}$ is positive, migrant households provide (receive) more private transfers than non-migrant households. If $\beta_{1}$ is negative, migrant

\footnotetext{
${ }^{6}$ The minimum number of villages in a rayon is 9 , the maximum 123.
} 
households provide (receive) less private transfers than non-migrant households. The same applies to remittance-receiving versus non-remittance-receiving households.

While this lagged model reduces concerns of simultaneity, the estimates may still be biased due to unobserved differences between migrant and non-migrant households. This is a cause of worry for us since the migrant and non-migrant households vary significantly across several observed socio-demographic dimensions, as we will see later. We address this concern by matching the migrant and non-migrant households on a wide range of variables using propensity score matching techniques.

\section{Data and Descriptive Statistics}

The data we use in our empirical analysis come from the Life in Kyrgyzstan (LIK) survey. This is a panel survey conducted annually between 2010 and 2012 by the German Institute for Economic Research (DIW Berlin) in collaboration with Humboldt-University of Berlin, the Centre for Social and Economic Research (CASE-Kyrgyzstan) and the American University of Central Asia (Brück et al. 2013). The LIK includes data from all seven Kyrgyz regions (oblasts) and the cities of Bishkek and Osh. Data are collected at the community, household, and individual levels of the sampled households. At the time of our data analysis, the first two waves (2010-2011) of the LIK were finalised. We mainly use data from the second wave because this provides more information on private transfers than the data from the first wave. In the second wave, 2,863 households in 120 urban and rural communities and 8,066 adult individuals within these households were interviewed. The total population in these households (including children) is 13,693.

The interviewed households were asked whether any of their regular members had been living abroad for more than one month (excluding business trips, vacations, and visits) during the last 12 months. ${ }^{7}$ Out of the 2,863 households, 485 reported to have one or more migrants, and 712 migrants were reported in total. This translates into 5 percent of the total sample being migrants. Based on the total resident population of 5,362,816 people counted in the 2009 Census, this means that there were approximately 268,141 international migrants in 2011. The range of estimates from other sources for the number of migrants is from 200,000 to more than one million migrants (Ablezova et al. 2009; Lukashova and Makenbaeva 2009;

\footnotetext{
${ }^{7}$ We are also able to estimate the number of internal migrants from the survey responses. We identify 231 internal migrants in 173 households. This translates into 1.69 percent of the sample population. This estimate appears to be low given that some people consider internal migration to be at least as important as international migration (Ablezova et al. 2009). It could be that, when people move internally, they often take their families with them. In that case, we would not observe them as migrants in our survey.
} 
Marat 2009; International Crisis Group 2010). Our estimate is at the lower bound of these. It is, however, close to the estimate from the 2009 Census, which was 190,000 migrants. This does not mean that the larger estimates of up to one million migrants are invalid. Surveys such as ours and the Census are usually unable to identify migrants who moved abroad with their families or moved a long time ago and are no longer regular members of a resident household. The number of 268,141 migrants should be interpreted as an estimate of the number of temporary labour migrants.

Table 1 provides information on the characteristics of the observed migrants. ${ }^{8}$ The average age of a migrant is 29 years. Two thirds of the migrants are male and almost half are married. Three quarters of the migrants are of Kyrgyz ethnicity, and the majority of them come from the South (Osh city, Osh, Jalalabad, and Batken oblasts) of the country. ${ }^{9}$ Ninety percent of the migrants have a secondary education degree or higher. They usually go to Russia and work in either construction or trade and repair. They send money home frequently, almost once every two months. The average amount of remittances was 54,000 Kyrgyz Soms (equivalent to approx. US\$1,200) in 2011.

\section{Table 1 about here}

We drop all urban households as well as households that have missing information on our key variables. Moreover, we now use information on migration from the first survey wave, which leaves us with 257 households that had a migrant abroad in the 12 months prior to the survey. Of these migrant households, 70 percent received remittances. This is a very high share and implies that the effects of migration are not easily distinguishable from the effects of remittances. In the estimation, we compare the transfer behaviour of a) households that have a migrant abroad with households that do not have a migrant abroad (257 vs. 1,368 households), and b) households that receive remittances with households that do not receive remittances (266 vs. 1,359 households). Given that these categories overlap to a large extent, we do not expect the results to deviate much from each other.

The following questions about transfer behaviour are asked in the individual questionnaire: ${ }^{10}$

\footnotetext{
${ }^{8}$ About 7 percent of the migrants are the head of the household. For these households, we re-define the head to be the second oldest person in the household (if the head was the oldest, which is most often the case) in order to compute the household head's characteristics to be used as a control variable in the estimations.

${ }^{9}$ See the Appendix for a choropleth map of Kyrgyzstan.

${ }^{10}$ The LIK contains some information about the partners in these transfer arrangements. Individuals were asked to what group their transfer partners mainly belonged. Partners were mostly relatives (between 60 and 73 percent for the four transfer categories). Other relevant groups are neighbours and friends, with neighbours being more important in the case of non-monetary transfers. This is in line with previous research, which found that family
} 
- To how many people did you give any financial help during the last 12 months?

- From how many people did you receive any financial help during the last 12 months?

- To how many people did you give any non-financial help (e.g. repairing house, preparing celebrations, homework help) during the last 12 months?

- From how many people did you receive any non-financial help (e.g. repairing house, preparing celebrations, homework help)during the last 12 months?

We compute four alternative household-level dummy variables (our dependent variables in the below estimations) from these four questions; the dummy variables indicate whether or not any household member provided transfers to others or received transfers from others. We do not use the information at the individual level because we assume that private transfers are made between households, not between individuals. This means that even if an individual provides physical help to someone else, it is a household level decision to do so. The first two variables ( $h$ _ give finhelp and $h$ h_rec_finhelp) take the value of 1 if any member of a particular household reported to have made or received a monetary transfer in the last year, and 0 otherwise. ${ }^{11}$ The other two variables ( $h h \_$give_nonfinhelpand $\left.h h \_r e c \_n o n f i n h e l p\right)$ take the value of 1 if any member of a particular household reported to have made or received a non-monetary transfer in the last year, and 0 otherwise. Out of the total number of rural households, about half provided monetary transfers to others, and half provided non-monetary transfers to others (Table 2). Two fifths of the households received monetary transfers, and 45 percent received non-monetary transfers. ${ }^{12}$ Households are not necessarily either pure givers or pure receivers. Of all those households that give or receive monetary transfers, 28 percent both give and receive. Among those that give or receive non-monetary transfers, 40 percent both give and receive. ${ }^{13}$

Table 2 about here

and kinship networks are most important to households' transfer behaviour and that geographic proximity matters (Fafchamps and Lund 2003; De Weerdt and Dercon 2006; Fafchamps and Gubert 2007; Munshi and Rosenzweig 2009; Mazzocco 2012).

${ }^{11}$ Financial transfers may include loans as well as gifts. In the third wave of the LIK, we ask the households to distinguish between loans that contain an interest, interest-free loans, and gifts.

${ }^{12}$ Cox, Jimenez and Jordan (1998) studied private transfers in Kyrgyzstan in the early 1990s. They find that only 12 percent of all surveyed households were net recipients and 9 percent net givers. However, their reference period is only 30 days, much shorter than ours.

${ }^{13}$ Figure A1 sheds some light on the difference between migrant and non-migrant households in terms of transfers made and received. The shares of migrant and non-migrant households are significantly different for all four transfer variables. Figure A2 illustrates differences in transfer behaviour between remittance and nonremittance households. Remittance and non-remittance households differ significantly on receiving monetary transfers and providing non-monetary transfers. 
In Table 3 (Panel A), we present descriptive statistics for the control variables, separately for migrant and non-migrant households; we test for differences in these characteristics in the two groups. ${ }^{14,15}$ Migrant households differ from non-migrant families on age and ethnicity of the household head as well as household size. Migrant households may be larger than non-migrant households either because only very large households send migrants abroad or because household members left behind by migrants join other households. The second option seems likely in the Central Asian context where the wife of a migrant is expected to co-reside with her parents-in-law when her husband is abroad.

Table 3 about here

\section{Estimation results}

The results of the estimation of equation (1) for migrant vs. non-migrant households as well as remittance vs. non-remittance households are shown in Table 4. Migrant households are 7 percentage points more likely than non-migrant households to provide monetary transfers and 9 percentage points less likely to receive monetary transfers. In addition, migrant households are 10 percentage points less likely than non-migrant households to provide non-monetary transfers. However, migrant households do not differ from non-migrant households in terms of receiving non-monetary help. We repeat the analysis with an indicator of whether a household receives remittances. Households that receive remittances are, in fact, 12 percentage points more likely than their non-receiving counterparts to make monetary transfers to others. Remittance receiving households are also 9 percentage points less likely to provide non-monetary transfers. However, there is no significant difference between remittance and non-remittance households in terms of receiving monetary or non-monetary help. $^{16}$

\section{Table 4 about here}

\footnotetext{
${ }^{14}$ In Table A1 in the Appendix, we define all variables that we use in the estimations and present summary statistics.

${ }^{15}$ Comparing the means of the control variables for remittance and non-remittance households shows a very similar pattern and is therefore not reported.

${ }^{16}$ We repeated this analysis with urban households. There is no difference in the transfer behaviour of migrant and non-migrant households as well as remittance and non-remittance households in urban areas. This finding is plausible for two reasons. First, credit and insurance markets are more developed in urban areas, and urban households therefore depend less on private transfers (to be used for risk sharing) than rural households. In addition, communities in urban areas are characterised by less repeated interactions and more information asymmetries compared with rural locations, which makes the exchange of private transfers more difficult (Cox and Jimenez 1998; Albarran and Attanasio 2003). Second, most of the migrants in Kyrgyzstan stem from rural areas. An effect on transfer behaviour is unlikely to show up in the data because of the few observations of urban migrants.
} 
As these results show, non-migrant households, or households that do not receive remittances, are more likely to provide non-monetary help than migrant households. This may be an indication that migrant households are labour constrained, because of the out-migration of adult members, so that they cannot spare anyone to provide labour help to others but may, instead, even need labour help themselves. Non-migrant households, in contrast, have adult members that can provide labour help to others. If migrant households indeed needed such help, we should find evidence of non-monetary help flowing to migrant, more so than to nonmigrant, households. However, as Table 4 shows, there is no association between migration or remittances and receiving non-monetary transfers. Possibly, the need for labour help depends on the composition of the household. For example, having dependants might imply greater time constraints for the household and, hence, a greater need for labour help. ${ }^{17}$ We check whether migrant households are more likely to receive non-monetary help when they have many dependants. We define dependants as members of the household who are younger than age 6 or older than 69 . We define a dependency ratio as the share of dependants in total household size. We interact this dependency ratio with migration status (Table 5). We find the interaction term to be positive and significant; migrant households with dependants are more likely than other households to receive non-monetary help. This is a sign that having a migrant abroad is not sufficient to receive help and having many dependants in the household is also not sufficient. Only if both conditions are fulfilled are households helped by others.

\section{Table 5 about here}

Overall, the analysis so far implies that migrant households are more likely to provide monetary help compared to non-migrant households. Non-migrant households, on the other hand, are more likely to receive monetary help and provide non-monetary help compared to migrant households. However, these results could be driven by unobserved differences between migrant and non-migrant households. To address such concerns, we use propensityscore methods to match migrant and non-migrant households along various dimensions. We then provide estimates of the effect of migration on private transfers using the matched sample. The covariates used in the matching include the same variables as in the above estimations as well as a number of additional household characteristics that are likely to

\footnotetext{
${ }^{17}$ Ablezova et al. (2009) provide evidence for elderly people living alone or with grandchildren in many Kyrgyz villages. In-depth interviews with the elderly show that migration of their adult children is a serious challenge for them.
} 
predict migration status. ${ }^{18}$ These are the household head's assessment of own risk aversion, whether or not the head is engaged in agriculture, whether or not the head still lives in the same oblast where he or she was born, and the ratio of dependants in total household size. We assume that these variables capture the unobserved differences between migrant and nonmigrant households as well as between remittance and non-remittance households. In particular, we assume that such characteristics as motivation or ability of household members that could drive migration and remittances are correlated with the education of the household head, the mobility of the head, his or her risk aversion, and the wealth index. If so, matching on these variables reduces unobserved heterogeneity by a large extent.

We define our treated group as households with migrants (remittances) one year ago and the control group as non-migrant (non-remittance) households. Using the kernel matching function, we construct propensity scores to match the treatment group to the control group. ${ }^{19}$ The kernel function takes the weighted averages of the observations in the control group as the counterfactual outcome for each observation. We apply Silverman's rule-of-thumb bandwidth 0.06. Standard errors are based on 200 bootstrapped replications.

Panel B in Table 3 reports the mean household characteristics for the migrant and the non-migrant households in the matched sample. In contrast to the unmatched samples in Panel A, the migrant and non-migrant households do not vary significantly across any dimension in the matched sample. The same picture emerges when comparing remittance with nonremittance households (unreported). This implies that the matching estimates, which are based on common support, are less likely to be driven by unobserved heterogeneity. ${ }^{20}$

The estimated mean differences in private transfer behaviour between treatment and control households, based on the matching, are reported in Tables 6 and 7. Overall, the matching results are similar to our probit estimates. We find that migrant households are 8 percentage points more likely to provide monetary transfers than non-migrant households in the matched sample. Similarly, non-migrant households are 10 percentage points more likely to receive monetary transfers than migrant households. The results look similar for remittance receiving households. However, unlike in our probit specification, we do not find evidence for differences between migrant (remittance) and non-migrant (non-remittance) households in terms of providing non-monetary help. The differences are in the same direction but they are not statistically significant.

\footnotetext{
${ }^{18}$ Specifically, we predict the migration status and remittance receipt in 2010 with household characteristics in 2010. We then compare transfer behaviour in 2011 for matched households that differed in migration or remittances in 2010.

${ }^{19}$ The results of the probit model are reported in Table A2 in the Appendix.

${ }^{20}$ Table A3 provides further evidence on the quality of matching.
} 


\section{Tables 6 and 7 about here}

In sum, what do our results imply in terms of the mechanisms outlined in section 2 ? If we assume that migrant households behaved like non-migrant households before migration, we can conclude that migration and remittances increase the extent of monetary transfers made within the community. We observe more monetary transfers made by migrant (remittance) households compared with non-migrant (non-remittance) households, which could mean that migrant (remittance) households insure their social networks against shocks (mechanism 5) or that they redistribute income to poorer households in the community (mechanism 7). ${ }^{21}$ In terms of non-monetary transfers, we find that migrant (remittance) households are less likely to provide labour help to other households. This was not confirmed in the matching. We therefore need to be careful when interpreting this result. We nevertheless propose an interpretation given that the signs of the results were the same. The finding could be a sign of decreased commitment in labour exchange arrangements (mechanism 3), which would imply a decrease in the extent of non-monetary transfers. However, it could also indicate that these households are disadvantaged in labour and do not have resources available to be shared with others, as already suggested above. We find some evidence for the fact that households with migrants receive more labour help (mechanism 4) but only if they have dependents. Which one of these two mechanisms dominates and, therefore, whether migration leads to an increase or a decrease in the extent of non-monetary transfers remains unresolved.

\section{Conclusion}

Economists have long engaged in understanding the role of migration and inter-household private transfers for managing households' risk in developing countries where insurance and credit markets are typically weak. Little is known about the interaction of these two risk management strategies in the communities of migrants' origin. Given the massive outmigration from some countries, such as Mexico and Kyrgyzstan, it is important to know the impact of migration on widely established private transfer systems. If these are weakened when many people migrate, governments may have to compensate for the loss of private transfers.

\footnotetext{
${ }^{21}$ Note that we cannot clearly distinguish between migrant and remittance households because most migrant households receive remittances.
} 
In this paper, we empirically assess the relationship between international migration and private transfers among households left behind in the migrant sending communities of rural Kyrgyzstan. Analysing household survey data, we find that migration is unlikely to lead to a weakening of private transfers. Migrant households are more likely than non-migrant households to provide monetary transfers to others and less likely to receive monetary transfers from others. This could be an indication that migrant households insure non-migrant households against income shocks or redistribute income to them. We also find some suggestive evidence that non-migrant households are more likely than migrant households to provide labour transfers. If these labour transfers were targeted at migrant households, which we cannot identify with our data, this could imply that households that are abundant in monetary resources provide monetary help to households that are labour abundant in return for labour help. In order to determine the direction and the motives of private transfers more clearly, future research and more detailed information on household transfer behaviour in migrant sending communities are needed. 


\section{References}

Ablezova, M., E. Nasritdinov, et al. (2009). The impact of migration on elderly people. Grandparent-headed households in Kyrgyzstan, Report by Help Age International Central Asia and Social Research Center, American University of Central Asia, http://src.auca.kg/pdf/The_impact_of_migration_on_elderly_people.pdf.

Albarran, P. and O. P. Attanasio (2003). Limited commitment and crowding out of private transfers: evidence from a randomised experiment. The Economic Journal 113(486): C77C85.

Brück, T., D. Esenaliev, et al. (2013) Household survey data for research on well-being and behavior in Central Asia. Journal of Comparative Economics DOI: http://dx.doi.org/10.1016/j.jce.2013.02.003

Coudouel, A., A. McAuley, et al. (1997). Transfers and exchange between households in Uzbekistan. Household welfare in Central Asia. J. Falkingham, J. Klugman, S. Marnie and J. Micklewright. London, Macmillan Press: 202-220.

Cox, D. (1987). Motives for private income transfers. Journal of Political Economy 95(3): 508-546.

Cox, D. and M. Fafchamps (2008). Extended family and kinship networks: economic insights and evolutionary directions. Handbook of Development Economics. T. P. Schultz, J. Strauss and H. B. Chenery. Amsterdam, Elsevier. 4: 3711-3784.

Cox, D. and E. Jimenez (1998). Risk sharing and private transfers: what about urban households? Economic Development and Cultural Change 46(3): 621-637.

Cox, D., E. Jimenez, et al. (1998). Family safety nets and economic transition: a study of private transfers in Kyrgyzstan. mimeo.

Cox, D. and M. R. Rank (1992). Inter-vivos transfers and intergenerational exchange. Review of Economics and Statistics 74(2): 305-314.

De Weerdt, J. and S. Dercon (2006). Risk-sharing networks and insurance against illness. Journal of Development Economics 81(2): 337-356.

Fafchamps, M. and F. Gubert (2007). The formation of risk sharing networks. Journal of Development Economics 83(2): 326-350.

Fafchamps, M. and S. Lund (2003). Risk-sharing networks in rural Philippines. Journal of Development Economics 71(2): 261-287.

Foster, A. D. and M. R. Rosenzweig (2001). Imperfect commitment, altruism, and the family: evidence from transfer behavior in low-income rural areas. Review of Economics and Statistics 83(3): 389-407.

Gallego, J. M. and M. Mendola (forthcoming). Labor migration and social networks participation in southern Mozambique. Economica. 
Giesbert, L., S. Steiner, et al. (2011). Participation in micro life insurance and the use of other financial services in Ghana. Journal of Risk and Insurance 78(1): 7-35.

Howell, J. (1996). Coping with transition: insights from Kyrgyzstan. Third World Quarterly 17(1): 53-68.

International Crisis Group (2010). Central Asia: migrants and the economic crisis. Asia Report No. 183, http://www.crisisgroup.org/ /media/Files/asia/centralasia/183\%20Central\%20Asia\%20Migrants\%20and\%20the\%20Economic\%20Crisis.pdf.

Kuehnast, K. and N. Dudwick (2002). Better a hundred friends than a hundred rubles? Social networks in transition. The Kyrgyz Republic. World Bank Economist's Forum Washington DC, World Bank. 2: 51-88.

Ligon, E., J. P. Thomas, et al. (2002). Informal insurance arrangements with limited commitment: theory and evidence from village economies. The Review of Economic Studies 69(1): 209-244.

Lucas, R. E. B. and O. Stark (1985). Motivations to remit: evidence from Botswana. Journal of Political Economy 93(5): 901-918.

Lukashova, I. and I. Makenbaeva (2009). Impact of the global financial crisis on labour migration from Kyrgyzstan to Russia. Qualitative overview and quantitative survey, Report by OSCE, ACTED and European Commission, http://www.osce.org/bishkek/40540.

Marat, E. (2009). Labor migration in Central Asia. Implications of the global economic crisis. Silk Road Paper, Central Asia - Caucasus Institute and Silk Road Studies Program, http://www.silkroadstudies.org/new/docs/silkroadpapers/0905migration.pdf.

Mazzocco, M. (2012). Testing efficient risk sharing with heterogeneous risk preferences. The American Economic Review 102(1): 428-468.

McKenzie, D., S. Stillman, et al. (2010). How important is selection? Experimental vs. nonexperimental measures of the income gains from migration. Journal of the European Economic Association 8(4): 913-945.

Morten, M. (2010). Sending home the riches: informal risk sharing networks and remittances. Paper presented at 2010 Conference of the North East Universities Development Consortium.

Morten, M. (2012). Temporary migration and endogenous risk sharing in village India. mimeo, http://pantheon.yale.edu/ mem226/Site/Research_files/JMP_Morten_Website.pdf.

Munshi, K. and M. R. Rosenzweig (2009). Why is mobility in India so low? Social insurance, inequality, and growth. NBER Working Paper No. 14850, Cambridge.

Ratha, D., S. Mohapatra, et al. (2011). Impact of migration on economic and social development. A review of evidence and emerging issues. World Bank Policy Research Working Paper No. 5558, Washington DC.

Rosenzweig, M. R. (1988). Risk, implicit contracts and the family in rural areas of lowincome countries. Economic Journal 98(393): 1148-1170. 
Schechter, L. and A. Yuskavage (2011). Reciprocated versus unreciprocated sharing in social networks. mimeo, http://www.aae.wisc.edu/lschechter/links.pdf.

Schokkaert, E. (2006). The empirical analysis of transfer motives. Handbook of the economics of giving, altruism and reciprocity. S.-C. Kolm and J. Mercier Ythier. Amsterdam, Elsevier. 1: $127-181$.

Stark, O. and R. E. B. Lucas (1988). Migration, remittances, and the family. Economic Development and Cultural Change 36(3): 465-481.

World Bank (2010). Migration and Remittances Factbook 2011. Washington DC, World Bank.

Yang, D. and H. Choi (2007). Are remittances insurance? Evidence from rainfall shocks in the Philippines. The World Bank Economic Review 21(2): 219-248. 
TABLE 1 - Characteristics of migrants

\begin{tabular}{|c|c|}
\hline Variables & All migrants \\
\hline \multirow[t]{2}{*}{$\mathrm{Age}^{a}$} & 29.04 \\
\hline & $(9.51)$ \\
\hline Male $^{b}$ & 68.3 \\
\hline Married $^{b}$ & 44.9 \\
\hline Kyrgyz $z^{b}$ & 71.1 \\
\hline Uzbek $^{b}$ & 21.1 \\
\hline Russian $^{b}$ & 1.7 \\
\hline Other ethnicity ${ }^{b}$ & 6.1 \\
\hline Basic education or below ${ }^{b}$ & 9.7 \\
\hline Secondary education ${ }^{b}$ & 76.8 \\
\hline University degree $^{b}$ & 13.5 \\
\hline In Russia ${ }^{b}$ & 91.9 \\
\hline In Kazakhstan ${ }^{b}$ & 6 \\
\hline In another country ${ }^{b}$ & 2.1 \\
\hline Comes from the South of Kyrgyzstan ${ }^{b}$ & 84.7 \\
\hline Comes from rural area ${ }^{b}$ & 69.9 \\
\hline Works in construction sector ${ }^{b}$ & 40.2 \\
\hline Works in trade and repair ${ }^{b}$ & 23.1 \\
\hline Works in hotels and restaurants ${ }^{b}$ & 10.7 \\
\hline Works in another sector ${ }^{b}$ & 26 \\
\hline \multirow[t]{2}{*}{ Frequency of remittances in the last year ${ }^{a}$} & 5.5 \\
\hline & (3.24) \\
\hline \multirow[t]{2}{*}{ Amount of remittances ${ }^{a, c}$ (in Kyrgyz Soms) } & 54,055 \\
\hline & $(51,370)$ \\
\hline$N$ & 712 \\
\hline
\end{tabular}

Source: Authors' illustration based on LIK survey data.

Note: Only migrants aged 15 and above are considered. Some of the characteristics are

based on only migrants that are abroad at the time of the survey. The LIK does

not collect data on the country of destination, the economic sector and the

remittances sent from migrants that have returned.

${ }^{a}$ Mean with standard deviation in parentheses.

${ }^{b}$ Proportion of migrants.

${ }^{c} 1$ USD $\approx 45 \mathrm{KGS}$. 
TABLE 2 - Prevalence of private transfers

\begin{tabular}{l|c|c}
\hline \hline & Monetary Transfer & Non-monetary Transfer \\
\hline How many households provided help? \\
\hline Yes, provided help & $782(48.1 \%)$ & $834(51.3 \%)$ \\
No, did not provide help & $843(51.9 \%)$ & $791(48.7 \%)$ \\
Total & $1,625(100 \%)$ & $1,625(100 \%)$ \\
\hline \multicolumn{3}{l}{ How many households received help? } \\
\hline Yes, received help & $645(39.7 \%)$ & $728(44.8 \%)$ \\
No, did not receive help & $980(60.3 \%)$ & $897(55.2 \%)$ \\
Total & $1,625(100 \%)$ & $1,625(100 \%)$ \\
\hline \hline
\end{tabular}

Source: Authors' illustration based on LIK survey data. 
TABLE 3: Summary Statistics

\begin{tabular}{|c|c|c|c|c|c|c|}
\hline \multicolumn{4}{|c|}{ Panel A: Unmatched Sample } & \multicolumn{3}{|c|}{ Panel B: Matched Sample } \\
\hline & $\begin{array}{l}\text { Non-migrant } \\
\text { households } \\
(N=1,368)\end{array}$ & $\begin{array}{c}\text { Migrant } \\
\text { households } \\
(N=257)\end{array}$ & Difference & $\begin{array}{l}\text { Non-migrant } \\
\text { households } \\
(N=1,161)\end{array}$ & $\begin{array}{c}\text { Migrant } \\
\text { households } \\
(N=251)\end{array}$ & Difference \\
\hline headage & 51.71 & 53.72 & $\begin{array}{c}-2.02 \\
(-2.11)\end{array}$ & 53.43 & 52.45 & $\begin{array}{c}0.98 \\
(0.88)\end{array}$ \\
\hline headmale & 0.77 & 0.72 & $\begin{array}{c}0.05 \\
(1.83)\end{array}$ & 0.66 & 0.66 & $\begin{array}{c}0.00 \\
(0.19)\end{array}$ \\
\hline headmarried & 0.74 & 0.79 & $\begin{array}{c}-0.05 \\
(-1.56)\end{array}$ & 0.78 & 0.81 & $\begin{array}{c}-0.03 \\
(-0.77)\end{array}$ \\
\hline headkyrgyz & 0.73 & 0.72 & $\begin{array}{c}0.01 \\
(0.31)\end{array}$ & 0.77 & 0.73 & $\begin{array}{c}0.04 \\
(0.98)\end{array}$ \\
\hline headuzbek & 0.10 & 0.21 & $\begin{array}{c}-0.11 \\
(-5.24)\end{array}$ & 0.16 & 0.21 & $\begin{array}{c}-0.05 \\
(-1.41)\end{array}$ \\
\hline headrussian & 0.06 & 0.01 & $\begin{array}{c}0.05 \\
(3.17)\end{array}$ & 0.02 & 0.02 & $\begin{array}{c}0.00 \\
(0.44)\end{array}$ \\
\hline headother & 0.11 & 0.05 & $\begin{array}{c}0.06 \\
(2.73)\end{array}$ & 0.05 & 0.05 & $\begin{array}{c}0.00 \\
(0.28)\end{array}$ \\
\hline yrs_schooling & 10.36 & 10.46 & $\begin{array}{c}0.10 \\
(-0.54)\end{array}$ & 10.77 & 10.35 & $\begin{array}{c}0.42 \\
(1.63)\end{array}$ \\
\hline hhsize & 5.09 & 5.54 & $\begin{array}{c}-0.45 \\
(-3.15)\end{array}$ & 4.97 & 4.82 & $\begin{array}{c}0.15 \\
(0.85)\end{array}$ \\
\hline wealth_index & 0.47 & 0.67 & $\begin{array}{c}-0.20 \\
(-5.17)\end{array}$ & -0.44 & -0.54 & $\begin{array}{c}0.10 \\
(1.68)\end{array}$ \\
\hline anygroupmem & 0.06 & 0.05 & $\begin{array}{c}0.01 \\
(0.80)\end{array}$ & 0.07 & 0.06 & $\begin{array}{c}0.01 \\
(0.50)\end{array}$ \\
\hline
\end{tabular}

Source: Authors' illustration based on LIK survey data.

Note: Panel A reports mean household characteristics (in 2011) for those households that had a migrant abroad in the year before the previous wave. Panel B reports mean household characteristics (in 2010) for the same households (on common support). Differences with t-statistics in parentheses. 
TABLE 4 - Association of migration and remittances with private transfers

\begin{tabular}{|c|c|c|c|c|c|c|c|c|}
\hline \multicolumn{9}{|c|}{ Probit model, reported are marginal effects } \\
\hline \multirow{2}{*}{$\begin{array}{l}\text { Variables } \\
\text { migrant_hh_lag }\end{array}$} & \multicolumn{2}{|c|}{ Give Monetary Help } & \multicolumn{2}{|c|}{ Receive Monetary Help } & \multicolumn{2}{|c|}{ Give Non-Monetary Help } & \multicolumn{2}{|c|}{$\begin{array}{c}\text { Receive Non-Monetary } \\
\text { Help }\end{array}$} \\
\hline & $0.0663^{*}$ & . & $-0.0867^{\star *}$ & . & $-0.0982^{\star \star}$ & . & -0.0700 & . \\
\hline & $(0.0369)$ & . & $(0.0424)$ & . & $(0.0394)$ & & $(0.0479)$ & . \\
\hline \multirow[t]{2}{*}{ remitt_hh_lag } & & $0.1221^{\star * *}$ & . & -0.0523 & 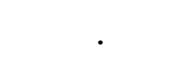 & $-0.0858^{\star *}$ & & -0.0402 \\
\hline & . & $(0.0373)$ & . & $(0.0407)$ & . & $(0.0428)$ & • & $(0.0450)$ \\
\hline \multirow[t]{2}{*}{ headage } & $0.0038^{\star \star \star}$ & $0.0036^{\star \star *}$ & 0.0011 & 0.0011 & 0.0008 & 0.0009 & 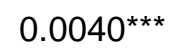 & $0.0040^{\star \star *}$ \\
\hline & $(0.0012)$ & $(0.0012)$ & $(0.0010)$ & $(0.0010)$ & $(0.0012)$ & $(0.0012)$ & (0.0012) & $(0.0012)$ \\
\hline \multirow[t]{2}{*}{ headmale } & 0.0517 & 0.0601 & 0.0230 & 0.0288 & -0.0262 & -0.0232 & $-0.1372^{\star \star \star}$ & $-0.1323^{\star \star \star}$ \\
\hline & $(0.0512)$ & $(0.0513)$ & $(0.0458)$ & $(0.0455)$ & $(0.0496)$ & $(0.0500)$ & (0.0493) & $(0.0487)$ \\
\hline \multirow[t]{2}{*}{ headmarried } & $0.1324 * \star \star$ & $0.1220 * \star \star$ & 0.0078 & 0.0054 & $0.0997^{*}$ & $0.1014^{*}$ & $0.2302^{\star \star \star}$ & $0.2276^{\star \star \star}$ \\
\hline & $(0.0448)$ & $(0.0458)$ & $(0.0465)$ & $(0.0472)$ & $(0.0517)$ & $(0.0524)$ & $(0.0419)$ & $(0.0418)$ \\
\hline \multirow[t]{2}{*}{ headkyrgyz } & 0.0371 & 0.0394 & 0.0346 & 0.0350 & 0.0855 & 0.0852 & 0.0601 & 0.0604 \\
\hline & $(0.0625)$ & $(0.0625)$ & $(0.0662)$ & $(0.0658)$ & $(0.1096)$ & (0.1097) & (0.0919) & (0.0918) \\
\hline \multirow[t]{2}{*}{ headuzbek } & $0.1851^{*}$ & $0.1888^{\star}$ & $0.2271^{\star \star *}$ & $0.2238^{\star *}$ & 0.0975 & 0.0942 & 0.0317 & 0.0306 \\
\hline & $(0.1035)$ & $(0.1042)$ & $(0.1017)$ & (0.1009) & (0.1458) & $(0.1476)$ & $(0.1428)$ & $(0.1435)$ \\
\hline \multirow[t]{2}{*}{ headrussian } & -0.0117 & -0.0114 & $-0.1536^{*}$ & -0.1503 & -0.1558 & -0.1523 & $-0.2534^{\star \star}$ & $-0.2500^{\star *}$ \\
\hline & $(0.0765)$ & (0.0773) & $(0.0915)$ & $(0.0919)$ & $(0.1242)$ & (0.1239) & $(0.1020)$ & $(0.1025)$ \\
\hline \multirow[t]{2}{*}{ hhsize } & $0.0193^{\star *}$ & $0.0202^{\star *}$ & 0.0015 & 0.0006 & $0.0300 * * *$ & $0.0288^{\star * *}$ & 0.0107 & 0.0099 \\
\hline & $(0.0086)$ & $(0.0087)$ & $(0.0072)$ & (0.0073) & (0.0088) & $(0.0087)$ & $(0.0092)$ & $(0.0092)$ \\
\hline \multirow[t]{2}{*}{ yrs_schooling } & $0.0118^{\star *}$ & $0.0116^{\star *}$ & -0.0032 & -0.0037 & 0.0081 & 0.0077 & 0.0033 & 0.0028 \\
\hline & $(0.0057)$ & $(0.0057)$ & $(0.0063)$ & $(0.0063)$ & (0.0053) & (0.0053) & $(0.0056)$ & $(0.0056)$ \\
\hline \multirow[t]{2}{*}{ anygroupmem } & 0.0771 & 0.0728 & $0.141{ }^{*}$ & $0.1469^{\star}$ & 0.0111 & 0.0181 & 0.0332 & 0.0374 \\
\hline & $(0.0636)$ & $(0.0642)$ & $(0.0782)$ & (0.0788) & $(0.0980)$ & (0.0983) & $(0.0872)$ & (0.0869) \\
\hline \multirow[t]{2}{*}{ wealth_index } & -0.0482 & -0.0466 & 0.0406 & 0.0406 & 0.0132 & 0.0118 & 0.0539 & 0.0539 \\
\hline & $(0.0382)$ & (0.0383) & $(0.0415)$ & $(0.0412)$ & $(0.0458)$ & $(0.0454)$ & $(0.0471)$ & $(0.0467)$ \\
\hline$N$ & 1,601 & 1,601 & 1,601 & 1,601 & 1,575 & 1,575 & 1,576 & 1,576 \\
\hline Pseudo-R ${ }^{2}$ & 0.140 & 0.143 & 0.182 & 0.181 & 0.202 & 0.201 & 0.210 & 0.209 \\
\hline
\end{tabular}

Source: Authors' calculation based on LIK survey data.

Note: Constant and community fixed effects are included. Numbers in brackets are standard errors (adjusted for clustering at village level).

*** significant at $1 \%$; ** significant at $5 \%$; * significant at $10 \%$. 
TABLE 5 - Association of migration with receiving non-monetary help, taking dependants into account

\begin{tabular}{lc|c}
\hline \multicolumn{2}{l}{ Different models, reported are marginal effects } \\
\multirow{2}{*}{ Variables } & \multicolumn{2}{c}{ Receive Non-Monetary Help } \\
& Probit & OLS \\
\hline migrant_hh_lag*depend & $0.3494^{\star *}$ & $0.2834^{\star}$ \\
& $(0.1737)$ & $(0.1535)$ \\
migrant_hh_lag & $-0.1224^{\star *}$ & $-0.0991^{\star *}$ \\
& $(0.0495)$ & $(0.0431)$ \\
depend & -0.0710 & -0.0537 \\
& $(0.0764)$ & $(0.0587)$ \\
HH Controls & YES & YES \\
\hline$N$ & 1,576 & 1,625 \\
(Pseudo) $R^{2}$ & 0.211 & 0.256 \\
\hline \hline
\end{tabular}

Source: Authors' calculation based on LIK survey data.

Note: Constant and community fixed effects are included. Numbers in brackets are standard errors (adjusted for clustering at village level).

*** significant at $1 \%$; ** significant at $5 \%$; * significant at $10 \%$. 
TABLE 6 - Matching Results: Private Transfers, Part 1 (Migration)

\begin{tabular}{lcccccc}
$\begin{array}{l}\text { Outcome } \\
\text { variables }\end{array}$ & Sample & $\begin{array}{c}\text { Migrant } \\
\text { households }\end{array}$ & $\begin{array}{c}\text { Non- } \\
\text { migrant } \\
\text { households }\end{array}$ & Difference & SE & T-stat \\
\hline $\begin{array}{l}\text { Give Monetary } \\
\text { Help }\end{array}$ & Unmatched & 0.5198 & 0.5004 & 0.0194 & 0.0348 & 0.56 \\
\hline Give Non- & Mntched & 0.5219 & 0.4410 & 0.0809 & 0.0480 & 1.69 \\
Monetary Help & Matched & 0.4263 & 0.4596 & -0.0333 & 0.0478 & -0.70 \\
\hline Receive & Unmatched & 0.3016 & 0.4376 & -0.1360 & 0.0341 & -3.99 \\
Monetary Help & Matched & 0.302 & 0.4047 & -0.102 & 0.0462 & -2.21 \\
\hline Receive Non- & Unmatched & 0.3849 & 0.4505 & -0.0656 & 0.0345 & -1.90 \\
Monetary Help & Matched & 0.3825 & 0.4149 & -0.0324 & 0.0473 & -0.69 \\
\hline$N$ Total & & & 1,413 & & & \\
$N$ On Support & & & 1,412 & & & \\
\hline \hline
\end{tabular}

Source: Authors' calculation based on LIK survey data.

Note: Kernel matching with common support (bandwidth=0.06). Standard errors are bootstrapped (200 replications). 
TABLE 7 - Matching Results: Private Transfers, Part 2 (Remittances)

\begin{tabular}{lcccccc}
$\begin{array}{l}\text { Outcome } \\
\text { variables }\end{array}$ & Sample & $\begin{array}{c}\text { Remittance } \\
\text { households }\end{array}$ & $\begin{array}{c}\text { Non- } \\
\text { remittance } \\
\text { households }\end{array}$ & Difference & SE & T-stat \\
\hline $\begin{array}{l}\text { Give Monetary } \\
\text { Help }\end{array}$ & Unmatched & 0.5538 & 0.4683 & 0.0855 & 0.0344 & 2.49 \\
\hline Give Non- & Matched & 0.5504 & 0.4669 & 0.0835 & 0.0419 & 1.99 \\
Monetary Help & Matched & 0.4264 & 0.4537 & -0.0273 & 0.0418 & -0.65 \\
\hline Receive & Unmatched & 0.3346 & 0.4236 & -0.0890 & 0.0338 & -2.64 \\
Monetary Help & Matched & 0.3333 & 0.4163 & -0.0830 & 0.0405 & -2.05 \\
\hline Receive Non- & Unmatched & 0.4000 & 0.4495 & -0.0495 & 0.0342 & -1.45 \\
Monetary Help & Matched & 0.3953 & 0.4266 & -0.0313 & 0.0415 & -0.75 \\
\hline$N$ Total & & & 1,379 & & & \\
$N$ On Support & & & 1,377 & & & \\
\hline \hline
\end{tabular}

Source: Authors' calculation based on LIK survey data.

Note: Kernel matching with common support (bandwidth=0.06). Standard errors are bootstrapped (200 replications). 


\section{APPENDIX}

Migration rates based on 2009 Census for Districts in Kyrgyzstan

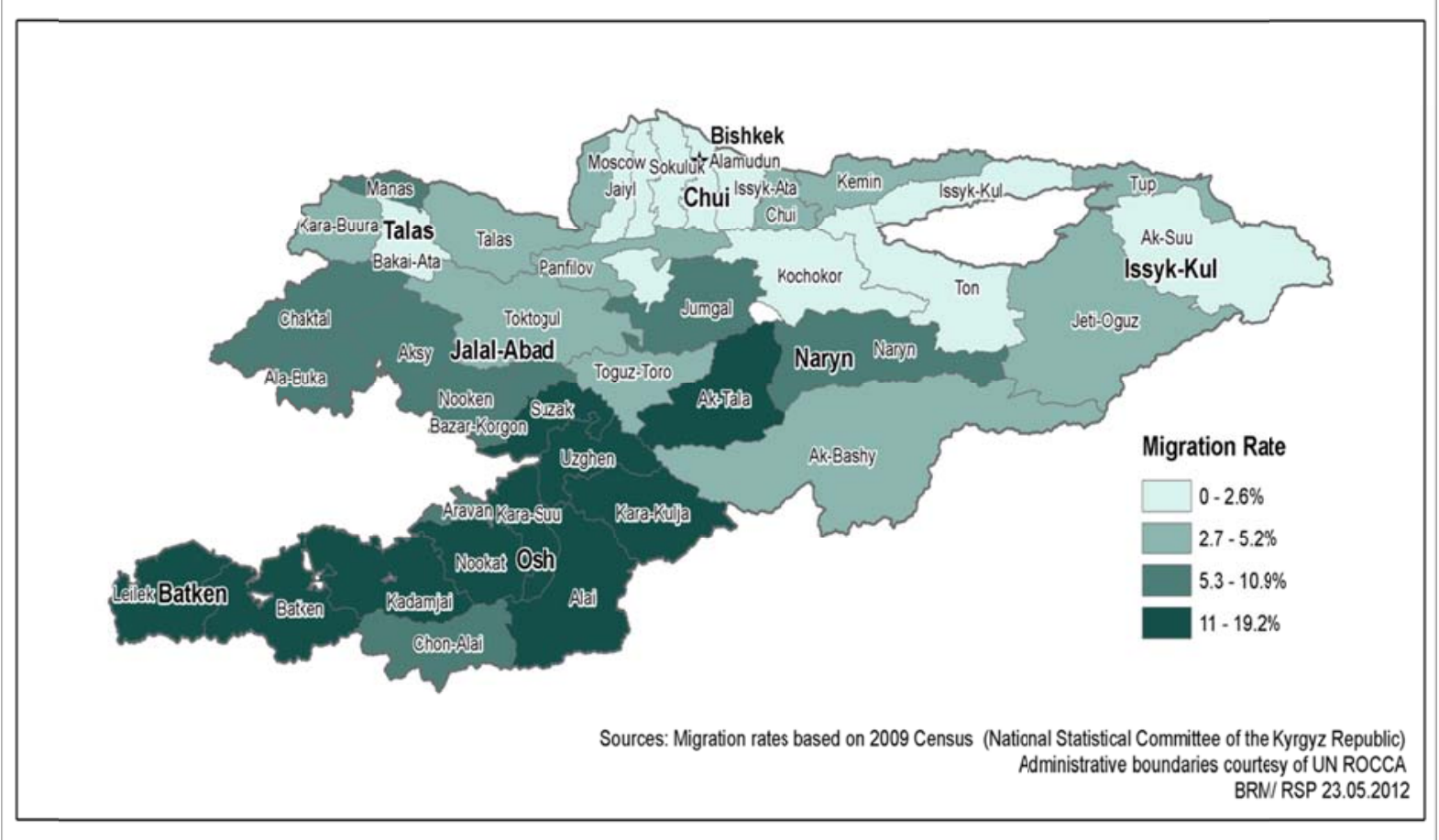

Source: Authors' illustration. 
TABLE A1 - Description of Variables

\begin{tabular}{|c|c|c|c|c|c|}
\hline Variable & Definition & Mean & SD & Min. & Max. \\
\hline migrant_hh_lag & 1=having had a migrant $12-24$ months ago, $0=$ otherwise & 0.16 & 0.36 & 0 & 1 \\
\hline remitt_hh_lag & $\begin{array}{l}\text { 1=having received remittances } 12-24 \text { months ago, } \\
0=\text { otherwise }\end{array}$ & 0.16 & 0.37 & 0 & 1 \\
\hline headage & age of household head in years & 51.9 & 14.1 & 18 & 99 \\
\hline headmale & $1=$ household head is male, $0=$ otherwise & 0.77 & 0.42 & 0 & 1 \\
\hline headmarried & $1=$ household head is married, $0=$ otherwise & 0.75 & 0.43 & 0 & 1 \\
\hline headuzbek & $1=$ household head is Uzbek, $0=$ otherwise & 0.12 & 0.32 & 0 & 1 \\
\hline headrussian & $1=$ household head is Russian, $0=$ otherwise & 0.05 & 0.22 & 0 & 1 \\
\hline headother & $1=$ household head is of another ethnicity, $0=$ otherwise & 0.10 & 0.30 & 0 & 1 \\
\hline yrs_schooling & years of schooling of household head in years & 10.36 & 2.66 & 0 & 15 \\
\hline depend & $\begin{array}{l}\text { ratio of household members older than } 69 \text { or younger than } \\
6 \text { in total household size }\end{array}$ & 0.17 & 0.20 & 0 & 1 \\
\hline headrisk & $\begin{array}{l}\text { standardised value for self-assessed willingness to take } \\
\text { risks }\end{array}$ & 0.03 & 0.96 & -1.62 & 1.83 \\
\hline headagri & $1=$ household head engaged in agriculture, $0=$ otherwise & 0.35 & 0.48 & 0 & 1 \\
\hline headmobility & $\begin{array}{l}1=\text { household head born in the oblast of current residence, } \\
0=\text { otherwise }\end{array}$ & 0.91 & 0.29 & 0 & 1 \\
\hline hh_give_finhelp & $\begin{array}{l}\text { 1=household provided monetary transfer, } 0=\text { otherwise } \\
1=\text { household provided non-monetary transfer, }\end{array}$ & 0.48 & 0.50 & 0 & 1 \\
\hline hh_give_nonfinhelp & $0=$ otherwise & 0.52 & 0.50 & 0 & 1 \\
\hline
\end{tabular}

Source: Authors' illustration based on LIK survey data. 
TABLE A2 - Propensity Score Estimation: Probit Regression for Migration and Remittances

\begin{tabular}{|c|c|c|}
\hline Variables & Dependent: Migration & Dependent: Remittances \\
\hline \multirow[t]{2}{*}{ headage } & $0.0163^{\star * *}$ & $0.0213^{\star \star *}$ \\
\hline & $(0.0035)$ & $(0.0036)$ \\
\hline \multirow[t]{2}{*}{ headmale } & $-1.2559 \star * *$ & $-0.9102^{\star \star \star}$ \\
\hline & $(0.1873)$ & $(0.1837)$ \\
\hline \multirow[t]{2}{*}{ headmarried } & $1.2069^{\star \star \star}$ & $1.0378^{\star \star \star}$ \\
\hline & (0.1968) & $(0.2034)$ \\
\hline \multirow[t]{2}{*}{ headkyrgyz } & -0.0978 & -0.0403 \\
\hline & $(0.2161)$ & $(0.2171)$ \\
\hline \multirow[t]{2}{*}{ headuzbek } & -0.0204 & -0.1027 \\
\hline & $(0.2630)$ & $(0.2727)$ \\
\hline \multirow[t]{2}{*}{ headrussian } & $-0.9424^{\star \star \star}$ & -0.1014 \\
\hline & $(0.3633)$ & $(0.3836)$ \\
\hline \multirow[t]{2}{*}{ hhsize } & $-0.0489^{*}$ & $-0.0601^{*}$ \\
\hline & $(0.0268)$ & $(0.0319)$ \\
\hline \multirow[t]{2}{*}{ yrs_schooling } & 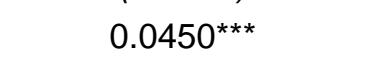 & $0.0480^{\star \star \star}$ \\
\hline & $(0.0155)$ & $(0.0175)$ \\
\hline \multirow[t]{2}{*}{ anygroupmem } & -0.1727 & -0.1615 \\
\hline & $(0.2406)$ & $(0.2464)$ \\
\hline \multirow[t]{2}{*}{ wealth_index } & 0.0447 & 0.0800 \\
\hline & $(0.0780)$ & $(0.0848)$ \\
\hline \multirow[t]{2}{*}{ headrisk } & -0.0138 & -0.0548 \\
\hline & $(0.0568)$ & $(0.0525)$ \\
\hline \multirow[t]{2}{*}{ headagri } & $0.2007^{\star \star}$ & 0.0716 \\
\hline & $(0.1021)$ & (0.0939) \\
\hline \multirow[t]{2}{*}{ headmobility } & -0.2932 & -0.0173 \\
\hline & $(0.1839)$ & $(0.1765)$ \\
\hline \multirow[t]{2}{*}{ depend } & $-0.4737^{\star \star}$ & $-0.4003^{\star}$ \\
\hline & $(0.2258)$ & $(0.2226)$ \\
\hline$N$ & 1,413 & 1,379 \\
\hline Pseudo- $R^{2}$ & 0.208 & 0.175 \\
\hline
\end{tabular}

Source: Authors' calculation based on LIK survey data.

Note: Constant and community fixed effects are included. Numbers in brackets are standard errors (adjusted for clustering at village level).

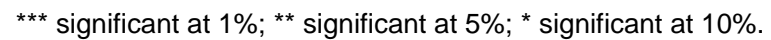


TABLE A3 - Summary of Matching Quality

\begin{tabular}{|c|c|c|}
\hline & Before Matching & After Matching \\
\hline \multicolumn{3}{|c|}{ Migration } \\
\hline $\begin{array}{l}\text { Mean Standardized } \\
\text { Bias }\end{array}$ & 14.0 & 4.4 \\
\hline $\begin{array}{l}\text { Median Standardized } \\
\text { Bias }\end{array}$ & 12.4 & 3.2 \\
\hline Pseudo- $R^{2}$ & 0.208 & 0.023 \\
\hline \multicolumn{3}{|c|}{ Remittances } \\
\hline $\begin{array}{l}\text { Mean Standardized } \\
\text { Bias }\end{array}$ & 12.0 & 11.0 \\
\hline $\begin{array}{l}\text { Median Standardized } \\
\text { Bias }\end{array}$ & 2.9 & 2.0 \\
\hline Pseudo- $R^{2}$ & 0.175 & 0.009 \\
\hline
\end{tabular}

Source: Authors' calculation based on LIK survey data. 
FIGURE A1 - Transfer behaviour in migrant vs. non-migrant households

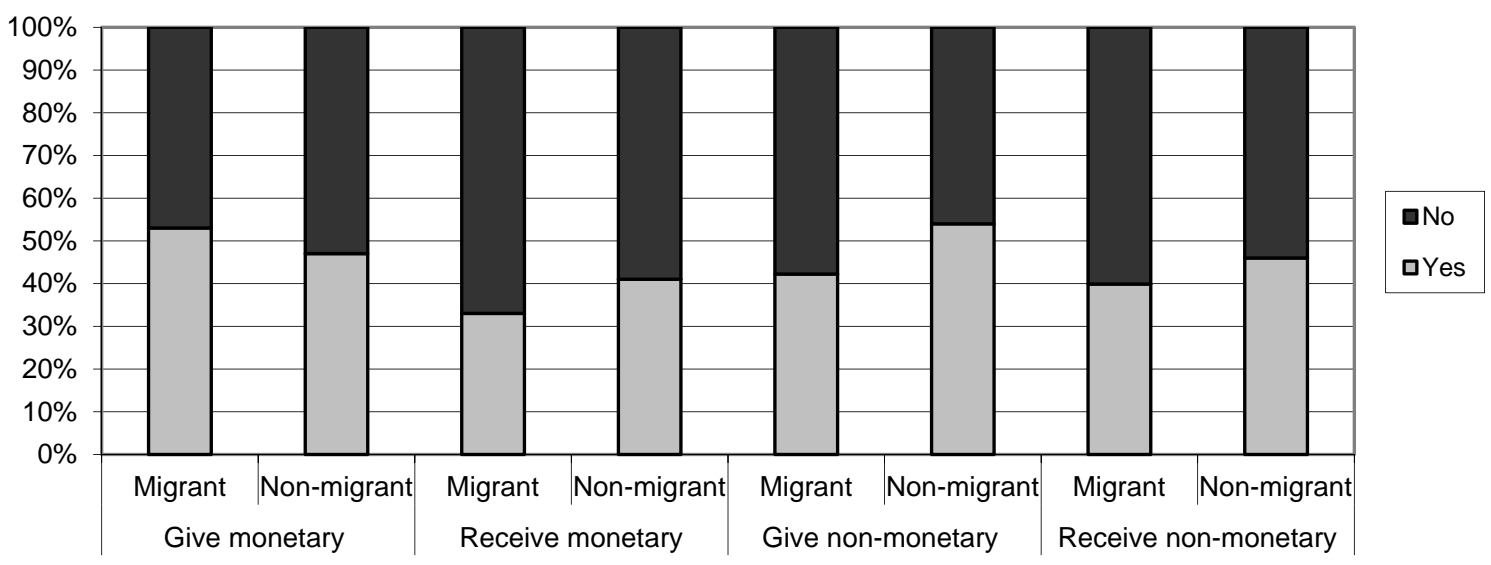

Source: Authors' illustration based on LIK survey data.

FIGURE A2 - Transfer behaviour in remittance vs. non-remittance households

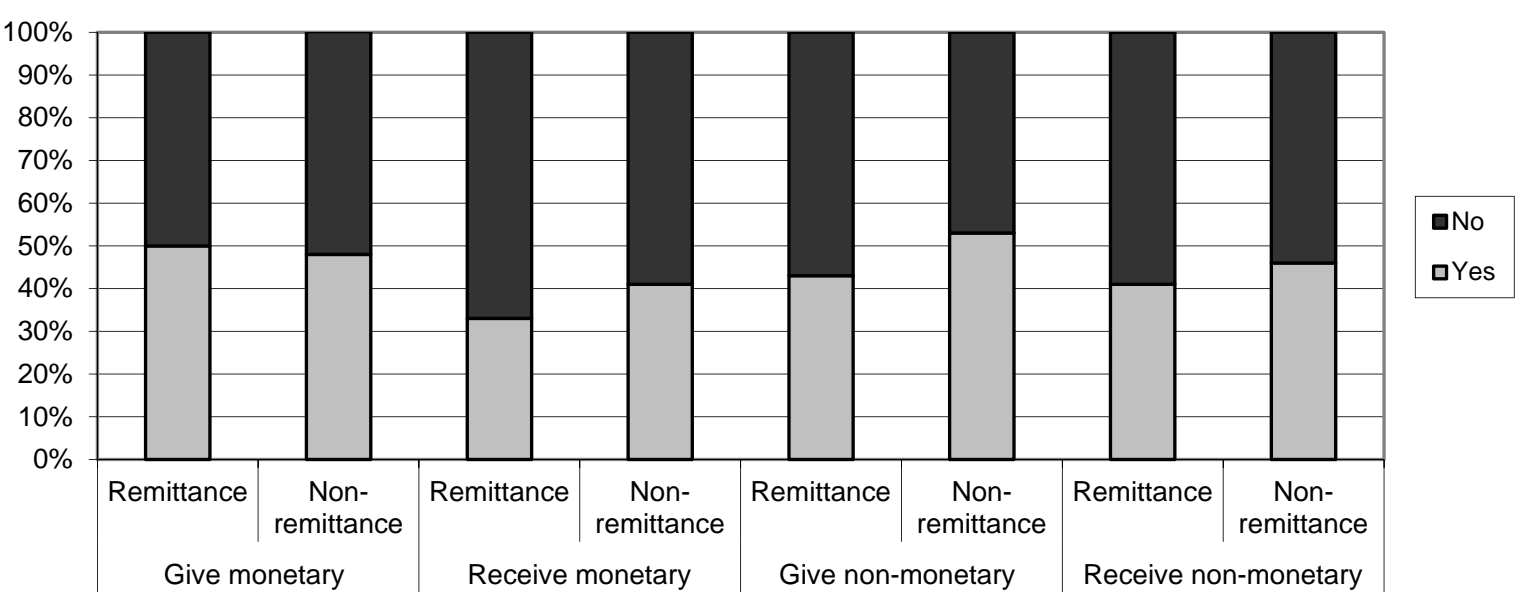

Source: Authors' illustration based on LIK survey data. 